\title{
ERRATUM
}

Open Access

\section{Erratum to: signatures of early frailty in the gut microbiota}

Matthew A. Jackson ${ }^{1}$, Ian B. Jeffery ${ }^{2}$, Michelle Beaumont ${ }^{1}$, Jordana T. Bell ${ }^{1}$, Andrew G. Clark ${ }^{3}$, Ruth E. Ley ${ }^{3}$, Paul W. O'Toole ${ }^{2}$, Tim D. Spector ${ }^{1}$ and Claire J. Steves ${ }^{1 *}$

\section{Erratum}

It has come to our attention that there is an error in one of the author names for this article [1]. The name of the first author was incorrectly listed as Matt Jackson but the correct name is Matthew A. Jackson. The original article has now been updated and the publisher apologises for any inconvenience caused.

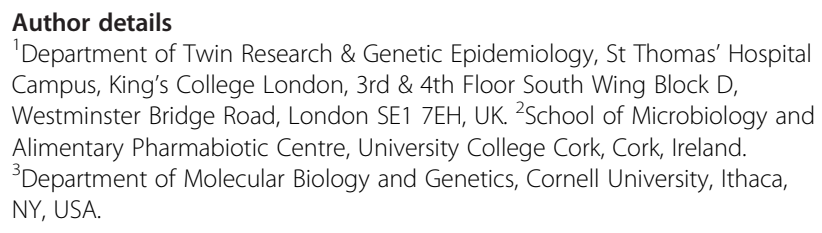

Published: 17 February 2016

\section{Reference}

1. Jackson MA, Jeffery IB, Beaumont M, Bell JT, Clark AG, Ley RE, et al.

Signatures of early frailty in the gut microbiota. Genome Medicine. 2016;8:8.

\footnotetext{
* Correspondence: claire.j.steves@kcl.ac.uk

'Department of Twin Research \& Genetic Epidemiology, St Thomas' Hospital Campus, King's College London, 3rd \& 4th Floor South Wing Block D, Westminster Bridge Road, London SE1 7EH, UK

Full list of author information is available at the end of the article
}

\section{Submit your next manuscript to BioMed Central and take full advantage of:}

- Convenient online submission

- Thorough peer review

- No space constraints or color figure charges

- Immediate publication on acceptance

- Inclusion in PubMed, CAS, Scopus and Google Scholar

- Research which is freely available for redistribution

Submit your manuscript at

www.biomedcentral.com/submit

() BioMed Central 